\title{
20. \\ KAZALIŠTE I GRAD - PRILOZI ZA \\ POVIJEST ZAGREBA KROZ RAZVOJ \\ NJEGOVA KAZALIŠTA NAKON II. \\ SVJETSKOG RATA (1945. - 1950.)
}

\section{Snježana Banović}

UDK: 792(497.5 Zagreb)“1945/50“

Izvorni znanstveni članak

Sažetak: U članku je riječ o uskoj povezanosti poslijeratnog razvoja grada Zagreba s razvojem njegova kazališta, koje je odmah nakon ulaska partizanskih trupa u grad, u svibnju 1945., prozvano Hrvatskim narodnim kazalištem. Ljeti iste godine, kad se u svim ustanovama kulture i prosvjete odvijaju procesi kažnjavanja na sudovima časti i kad nova kazališna uprava na čelu s Ivom Tijardovićem priprema svoju prvu sezonu, kulturni život Zagreba polako se uspostavlja unatoč teškim poratnim ekonomskim prilikama te postupno dolazi do metamorfoze njegova kulturnoga sustava. Iako se grad u to doba snabdijeva racionaliziranim artiklima preko državnih ustanova jer je trgovački distribucijski aparat još preslab te vladaju teške ekonomske, financijske i komunalne prilike, u kazalištu se od rujna 1945. svakodnevno, na dvjema scenama, izvodi zahtjevan umjetnički program te se ono postavlja u sâm centar gradskih i republičkih zbivanja. Iako, osim kazališnoga poleta i dotad rijetko u povijesti zabilježenoga uzleta njegovih obiju umjetničkih grana - one dramske i one glazbene - pod utjecajem agitpropizacije društva dolazi i do ekstenzivne kontrole i nadzora Partije te premještanja umjetnika u novoosnovana kazališta širom zemlje, na daskama središnjeg kazališta NRH, koje je redovito i prostor javnih svečanosti, prisutna je u ovom petogodišnjem razdoblju značajna transformacija repertoara, publike i kritike.

Ključne riječi: Narodna Republika Hrvatska, Zagreb, nova kulturna i kazališna politika, Hrvatsko narodno kazalište, Zagreb, Agitprop kultura

I.

dmah nakon osnivanja Antifašističkoga vijeća narodnog oslobođenja Jugoslavije (AVNOJ) te uskoro i Zemaljskog antifašističkog vijeća narodnog oslobođenja Hrvatske (ZAVNOH) kao najvišeg organa državne vlasti u Federalnoj državi Hrvatskoj, dolazi do uspostave osnovnih smjernica nove kulturne politike. Već tri mjeseca prije ulaska 
partizanskih trupa u Zagreb, Predsjedništvo AVNOJ-a je „u svrhu sređenja materijalnih i personalnih prilika HNK u Zagrebu“ odlučilo da se „iz razloga potpune aktivizacije i obnove kulturno-umjetničke strane ove hrvatske narodne institucije u smislu današnjih potreba i nastojanja“, što prije imenuje Uprava Hrvatskog narodnog kazališsta. ${ }^{1}$ Prethodno je, već početkom rujna 1944., Odjel informacija ZAVNOH-a uputio svom Predsjedništvu priopćenje s detaljno razrađenim planom preuzimanja svih prosvjetno-kulturnih ustanova nakon ulaska partizana u Zagreb. U točki VII. toga dopisa zahtijeva se da se za hrvatsko kazalište odmah imenuje intendant. ${ }^{2}$

U trenutku ulaska prvih partizanskih jedinica u Zagreb, 8. svibnja 1945. poslijepodne, prošlo je gotovo mjesec dana od formiranja prve Narodne Vlade Hrvatske u Splitu te ona, uz predsjednika i dvojicu potpredsjednika, ima i jedanaestoricu ministara, među kojima je i Ante Vrkljan, ministar prosvjete, u čiji resor ulazi i kultura te koji uskoro imenuje i novu, zasad privremenu Upravu HNK-a s Ivom Tijardovićem na čelu, još uvijek aktualnim intendantom Kazališta narodnoga oslobođenja Hrvatske (KNOH). Upravu nad Zagrebom, pak, najprije preuzima Vojna komanda, na čijem je čelu Većeslav Holjevac, da bi potom predsjednikom Gradskog odbora bio imenovan Dragutin Saili, koji će na toj dužnosti ostati do 1948., a njegov povjerenik za prosvjetu i kulturu bit će istaknuti profesor i sudionik u obama svjetskim ratovima Antun Kajfeš. ${ }^{3}$

Iako su obje kazališne zgrade (velika na Kazališnom trgu i mala u Frankopanskoj ulici, danas GDK „Gavella“) tijekom rata ostale sačuvane, kazalište je zatečeno u potpunom rasulu i dezorganizaciji, $s$ inventarom koji je „velikim dijelom bio uništen i opljačkan“ te je stoga „postojalo još samo po imenu.“" Ipak, članstvo se tek djelomično osulo te je dolaskom partizana u Zagreb bilo uglavnom na broju. ${ }^{5} \mathrm{U}$ novim je okolnostima „pritajena života čekalo bolje dane“, započevši s poslijeratnim radom znatno „podsječenih krila.“6

\section{2.}

Partizanska trupa KNOH-a stigla je u Zagreb iz Splita, uvečer 9. svibnja, a već sljedećeg jutra njezini su članovi kamionom dovezeni tik pred glavni ulaz u kazalište. Na kamionu

1 Zavod za povijest hrvatske književnosti, kazališta i glazbe Hrvatske akademije znanosti i umjetnosti (dalje: HAZU), Odsjek za povijest hrvatskog kazališta, Muzejsko-kazališna zbirka dokumenata: 18117.

2 Drago Roksandić i Vlatka Filipčić Maligec, Prvi kongres kulturnih radnika Hrvatske (Topusko, 25. - 27. lipnja 1944.). Između „mjesta pamćenja i kritičke refleksije“, Zagreb 2016., 295.

3 „Prof. dr. Antun Kajfeš“, Hrvatski državni arhiv (http://daz.hr/prof-dr-antun-kajfes/)

4 Ivica Krizmanić i Ljudmil Gotcheff, Naša kazališta. Dokumenti naše stvarnosti, Zagreb 1955., 45.

5 Iz kazališta i iz Zagreba, u svibnju 1945., pobjeglo je sveukupno osmero članova. Iz Drame arhivar Ivan Krmpotić, koji je od 1943. bio u ustaškoj vojnici u činu poručnika, glumica Dragica Krog-Radoš, u angažmanu od 1944., čiji je suprug bio u vojnici i koja je preko Austrije otišla u SAD, te Josip Pukšec, najaktivniji ustaša u kazalištu tijekom cijelog rata. Iz Opere: šaptač Mladen Žigrović, zboristi Franjo Šantić i Dragutin Varga, od 1942. član Vijeća HKKUa, predsjednik Upravnog odbora Bolesničke zadruge kazališta i stožerni časnik OS-a NDH. Od tehničkog osoblja otišao je u zbjeg prema Bleiburgu i ondje najvjerojatnije stradao električar Vjekoslav Giriček. Više o kazališnim zbivanjima u prvim danima prevrata u svibnju 1945., u: Snježana BANović, Država i njezino kazalište, Zagreb 2012., $345-360$.

6 Nikola Batušıć, Povijest hrvatskoga kazališta, Zagreb 1978., 472. 
bila je i Irena Kolesar, mlada partizanka koja je glumački zanat učila tijekom ofenziva, a svoj prvi dan u zagrebačkom kazalištu, u kojem će sljedećih osam godina nastupati u velikim ulogama, gledala je kao na bajku:

Ujutro pred HNK. Svi. Članovi, povratnici i mi, novajlije. Svi se ljubimo. Fotografiraju nas pred zgradom. Odmah nas je netko predstavio starijima... svi, svi su bili divni kolege. ${ }^{7}$

Iste je trenutke opisao i njezin kolega te budući dramatičar Pero Budak, koji je kao sudionik i pomagač NOP-a cijeli rat proveo u zagrebačkom ansamblu:

Kad se iz kamiona s glumcima iskrcao glumac Joža Rutić, svi smo se sjatili oko njega da ga pozdravimo. Nosio je odoru s činom partizanskog kapetana. Nije izbjegavao rukovanje, iako je svakog odmjerio od glave do pete nije li možda bio ustaša ili je u nečem pogriješio. ${ }^{8}$

O događanjima prvih dana uspostave nove vlasti govorio je, ne skrivajući prezir, tada već bivši šaptač u Operi i budući emigrant u Španjolskoj Mladen Žigrović, koji će prije odlaska u emigraciju neko vrijeme provesti u zatvoru na Kanalu:

Antun Boglić se sada našao među prvacima zagrebačkog kazališta (...) sakupio je cjelokupno kazalište, doveo usto nekakve harmonikaše, pa svi zaplesali partizansko kolo i to uokolo čitave zgrade opere. (...) Uz borce s terena, s nabijenim šajkačama i pištoljima oko pasa, izmilili su i „heroji“ iz pozadine: August Cilić, a za njim i nekolicina drugih iz nove intelektualne i umjetničke elite: Joža Kavur sa ženom Biankom Dežman, Stevo Vujatović, krojač Šustić (Šukić - op. a.), čelist Pajo Stojković... već su prvih dana uspostavili nekakav „narodni sud.“"

Sud koji spominje Žigrović bio je tzv. Sud časti, koji se osnivao u svim ustanovama prosvjetno-kulturne važnosti u kojima su, uz članove tih ustanova, obvezno imenovani i oficiri OZNA-e, a odlučivao je o kaznama za one umjetnike i kulturne djelatnike koji bi potom „privremeno ili trajno“ dobili zabranu djelovanja jer su bili „fašisti, služili vjerno okupatorima i ustašama. " ${ }^{10} \mathrm{U}$ kazalištu je Sud časti formiran u kasno ljeto 1945., odmah nakon pokretanja Anketne komisije za utvrđivanje zločina kulturnom suradnjom s neprijateljem ${ }^{11}$ te je uskoro kaznio velik broj članova obaju ansambala, uglavnom gubitkom prava nastupa od mjesec dana do šest mjeseci i usto zabrane javnog djelovanja. Stoga sve do jeseni 1945.,

7 Irena Kolesar, „Dnevnički zapisi i sjećanja iz partizana. Izvodi 1943.-1945. godina“ (odabrala i priredila Mira Šuvar), Hrvatska ljevica, VIII/2002., br. 9, 30-31.

8 Pero Budak, Živeći život (rukopis u arhivi Nevena Budaka), 4.

9 Mladen Žıgrović, $U$ žitu i kukolju, München - Barcelona 1986., 196.

10 Popis književnika kojima se dopušta objavljivanje djela u našem tisku, Hrvatski državni arhiv (dalje: HR-HDA-1220), fond Komisija za agitaciju i propagandu CK KPH 1945. - 1954. (dalje: Agitprop), fasc. Kult. umj. rad (I. dio) 1945./1954., kut. 10 .

11 Anketna komisija imala je zadatak ispitati sve osobe koje su javno djelovale za vrijeme NDH - uz glumce i pjevače, još i novinare, publiciste, urednike, književnike, likovne umjetnike, glazbenike, zaposlenike radija, sveučilišne profesore, članove uprava kulturnih i prosvjetnih institucija. Osnovna joj je aktivnost bila slanje tzv. upitnih araka na adrese svih kulturno-prosvjetnih ustanova u Hrvatskoj na području svih NOO-a u ukupno 29 gradova. Uprave su ih morale dostaviti svim članovima i suradnicima na ispunjavanje. Svako prešućivanje ili navođenje pogrešnih podataka bilo je kažnjivo. Upitni arci sastojali su se od osobnih podataka u kojima je trebalo navoditi aktivnosti za vrijeme NDH, eventualna odlikovanja, pripadnost ustaškoj organizaciji i odnos prema NOP-u. HR-HDA-306, fond Zemaljska komisija za utvrđivanje zločina okupatora i njihovih pomagača Hrvatske, Anketna komisija za utvrđivanje zločina kulturne suradnje s neprijateljem (dalje: AK) 1941. - 1946., kut. 686. 
tj. do početka prve Tijardovićeve sezone u kazalištu neće biti novih scensko-glazbenih produkcija - na objema scenama odvijat će se sporadični programi partizanskih trupa, koje su u tom trenutku jedine smjele nastupati. Osim njihovih šarenih programa, sve do početka nove sezone prikazuju se i različiti prigodni te svečani programi prema narudžbi državnih tijela i Partije. No, već u listopadu 1945. dokinute su sve preostale kazne izrečene na Sudu časti i on je ukinut. Proslavljeni prvak zagrebačkoga glumišta Tito Strozzi, i sâm prethodno kažnjen s četiri mjeseca zabrane igranja, najbolje je opisao nedostatak kriterija tih ad hoc sudskih vijeća:

Krivica kazališnih članova vrlo je relativna stvar. U stvari, svi smo mi jednako šutke kolaborirali u službenom radu teatra, od najzaslužnijeg člana NOP-a koji je prije svog odlaska (u partizane - op. a.) radio na pokusima i predstavama do nas izopćenika. Pokazalo se doduše da oni koji su otišli u partizane, pa bilo to tek onda kad je pobjeda bila očita i kad je ljudima osjetljivije savjesti bilo malo neugodno pomišljati na takav prijelaz, nisu sa sebe mogli zbrisati sjenku da su to uradili zbog računa. ${ }^{12}$

Ipak, za one koji su bili otpušteni iz kazališta, u tom kratkom, ali intenzivnom razdoblju tranzicije u novi sustav kulturne politike, koji je s Partijom na čelu trebao služiti revolucionarnoj preobrazbi cijeloga društva, nije bilo amnestije jer su „njihovi delikti bili teže prirode. "13 Budući intendant Marijan Matković, četiri godine nakon ovih događanja u jednom je dopisu Agitpropu napisao da „umjesto umjetničkog poleta, koji se očekivao, umjesto oživljavanja za vrijeme okupacije uvriježenog artističkog mrtvila, došla su premještanja, kazne, šikaniranja." U to vrijeme intendant HNK-a tek tri mjeseca, taj rijetki glas razuma u tadašnjoj sovjetski zacrtanoj kulturi Agitpropa, oštro je osudio komesarijatsko ponašanje osloboditelja:

To potpuno neznalačko tretiranje dramskih ansambala (koji se stvaraju godinama), to nasilno stvaranje nesigurnosti u njima, guranje pojedinaca u tabor reakcije - koji nikad reakcionari bili nisu, podržavanje afera, sitno špijuniranje - sve to kao metod rada u prvoj sezoni poslije Oslobođenja, metod podržavan i inspiriran od Ministarstva prosvjete kao operativnog rukovodstva, toleriran od partijske jedinice HNK i od uprave HNK stvorio je tako duboke rane u živom tkivu kazališta da one još do danas nisu zacijelile. ${ }^{14}$

Kazalište su, osim razjedinjenosti ansambla, morili i brojni drugi, tekući problemi, a ponajveći među njima bila je preopterećenost umjetnika pa se u cijelom aktivnome dijelu ansambla, kojem je bilo dopušteno nastupati, osjećala „zamorenost i naročito osjetljivost za bolesti.“ U zapisniku Drame iz kolovoza 1945. navodi se da je sve to „posljedica rata, slabih prehrambenih navika, četverogodišnjeg rada bez oporavka i konačno - neprijateljskog terora pod kojim su umjetnici istrošili svoje živce." ${ }^{15}$ Angažiranjem niza mladih glu-

12 Eliza Gerner, Oteto zaboravu, Zagreb 1995., 10-11.

13 Dopis Antuna Boglića, tajnika Opere personalnom odjelu Ministarstva prosvjete NRH, HR-HDA-291, fond Ministarstvo prosvjete Republike Hrvatske (dalje: MINPRO RH), fasc. 13.3.4. VIII 46a - Osobni spisi: 10514 , kut. 56.

14 Marijan Matković, Izvještaj o kazališnoj problematici u NR Hrvatskoj sa specijalnim težištem na problematiku Hrv. nar. kazališta, 20. I. 1950., HR-HDA-1220, Agitprop, fasc. Kazališta - HNK u Zagrebu, 1946. - 1950., bez br., kut. 10

15 Izvještaj Drame za VIII. 1945., HAZU, Odsjek za povijest hrvatskog kazališta, Muzejsko-kazališna zbirka dokumenata: 18068 . 
maca, plesača i pjevača, koji su se priključili ansamblu kao članovi KNOH-a tijekom rata, ali i odmah nakon oslobođenja i koji prije rata nisu imali nikakvo scensko obrazovanje i iskustvo ili su tek bili izašli iz Glumačke škole, dobilo je kazalište tek talentiran pomladak.

Kako je uskoro postalo jasno da pomlađen, ali nedovoljno stručan partizanski ansambl ne može ispuniti plan i umjetničke zahtjeve kazališne kuće na razini Hrvatskog narodnog kazališta, u rad su uskoro uključeni svi suspendirani. Među njima je i spomenuti Tito Strozzi, koji zbog odsutnosti Branka Gavelle iz Zagreba te nedostatka profesionalnih redatelja već na početku prve poratne sezone dobiva režiju Bizetove Carmen. Isto se dogodilo i jednom od najvećih europskih tenora toga vremena, Josipu Gostiču, koji je, iako još uvijek pod kaznom zabrane nastupanja, doživio veliku zadovoljštinu kao Cavaradossi na prvoj poslijeratnoj izvedbi Tosce, na koju je nahrupila zagrebačka publika, ispunivši kazalište do posljednjeg mjesta. Čim se glasoviti tenor pojavio na sceni, ovacijama nije bilo kraja; cijelim se gledalištem zaorilo skandiranje „Jo-ža! Jo-ža!“.

A tek kad je zapjevao... Zar ima ljepših slika, pomislio sam u tom trenutku. (...) Tek mi je u pauzi netko pristupio (...) rekavši mi kako je sramota za zagrebačku publiku što tako urnebesno i provokativno pozdravlja tenora koji je redovno nastupao za vrijeme okupacije i sada prvi put pjeva nakon pravedno izrečene tromjesečne kazne, dodavši kako je vidio da sam i ja odobravao. Kako i ne bih, rekao sam na to, četiri mi je godine manjkao taj savršeni glas. Sretan sam što sam na životu i zahvalan sudbini da opet mogu u njemu uživati. ${ }^{16}$

No, one bez kojih se moglo dalje, a usto su se i zamjerili novoj vlasti zbog angažmana tijekom NDH, premještalo se (u skladu s glavnim načelom kulturne politike o obnovi starih i izgradnji novih kazališta posvuda gdje za to postoji interes i barem minimalne mogućnosti) u nova kazališta, koja su nicala u pokrajinskim središtima. Osnivanje njihovih ansambala bio je velik problem jer je rijetko tko želio otići iz Zagreba - većina potencijalnih članova ansambala u stvaranju nadala se ostanku, zatrpavajući Upravu molbama za ostankom u Zagrebu, tj. u HNK-u. Glumci su bili najuporniji u toj namjeri. Željko Frelić, primjerice, želio je uz glumu studirati i povijest umjetnosti te filozofiju, a i njegova se zaručnica (balerina, uskoro i glumica Zdenka Heršak - op. a.) spremala za glumački zanat, očekujući skoro otvaranje Glumačke škole, „a ta će biti osnovana samo u Zagrebu. ${ }^{\text {"17 }}$ Kako ostati u Zagrebu nije bio samo problem mladih umjetnika na početku karijere - veteranka Jelena (Elena) Manjkovska s bogatim predratnim i ratnim stažem u kazalištu navela je kao jak argument to da joj je sin bio borac XXI. srpske proleterske divizije te da se „borio od Beograda do oslobođenja Zagreba“, gdje se sada školuje pa bi je njezin odlazak iz Zagreba spriječio da bude uz njega jer ga nije vidjela „za čitavo doba okupacije.“ U Zagrebu živi i

\footnotetext{
16 Branko Polić, Imao sam sreće. Autobiografski zapisi, II. dio (1. XI. 1942. - 22. XII. 1945.), Zagreb 2006., 380-381.

17 Dopis glumca Željka Frelića Upravi HNK, 4. VII. 1945., HAZU, Odsjek za povijest hrvatskog kazališta, Muzejskokazališna zbirka dokumenata: 583331 .
} 
njezin muž te bi premještaj tako poremetio i njezin bračni život. ${ }^{18}$ Većina je u svojim molbama navodila da bi im zdravstveno, bračno ili materijalno stanje bilo ugroženo u slučaju odlaska iz Zagreba te da je ostanak ključan za njihovu egzistenciju. Bogumila Nučić-Careva, koja je kao ključan razlog za ostanak u Zagrebu navela tešku sinovu bolest, ponudila je svojevrsno „rješenje“ u činjenici da se

u Zagrebu nalazi [se] mnogo glumica koje nemaju djece, nisu politički izgrađene, štaviše, nisu uopće uz današnji poredak, a ima i takvih koje ne posjeduju naročiti talent. Pa ipak, one su u Zagrebu, a ja moram da žrtvujem sve što je njima dano i porodicu i udobnost stanovanja i stotinu drugih stvari te da se potucam okolo. ${ }^{19}$

Argument koji se većini od njih također činio odlučujućim u prilog ostanka u Zagrebu bio je i taj da im je ustaška država uništila obitelj i imovinu, da su na liniji Partije i politički pravilno izgradeni. Boris Vrsalović je, uz skrb za „maloga brata koji je u gluhonijemoj školi“, smatrao da razlozi za njegov ostanak u Zagrebu leže u njegovu političkome djelovanju - bio je, naime, član-volonter Gradskoga odbora Ujedinjenog saveza Antifašističke omladine Hrvatske (USAOH), gdje je obavljao dužnost referenta za kazalište i umjetnost te vodio omladinsku radioemisiju. ${ }^{20}$ No, ni njemu, kao ni velikoj većini molbi nije bilo udovoljeno - nova su kazališta hitno trebala glumce, plesače i glazbenike, a Zagreb ih je imao i previše pa je velik broj njih morao otići u Rijeku, Varaždin, Bjelovar, Split, Osijek... Jedan od rijetkih koji su uspjeli te prve poslijeratne sezone ostati u zagrebačkome kazalištu bio je Radojko Ježić, predratni volonter, koji je svojim potresnim pismom odobrovoljio Upravu te uskoro postao član Drame, gdje je ostao tri sezone - do osnutka Zagrebačkog dramskog kazališta na Kaptolu (1948.):

Izdržavam svoju drugaricu (ženu) koja je invalid (bez lijeve noge) te je nesposobna za kretanje i posao, a još nema ni definitivne proteze, zato joj je potreban liječnički na(d)zor i obučavanje hodanja u fiskulturnom ortopedskom zavodu u te svrhe, koji još za sada postoji samo u Zagrebu. ${ }^{21}$

Po svemu sudeći, ipak je prevagnulo to što je Ježić bio sudionik NOB-a, a usto i član Centralne kazališne družine „August Cesarec“, potom i Centralne kazališne družine pri ZAVNOH-u, čime se ostali brojni aspiranti na mjesto u ansamblu zagrebačke Drame nisu mogli pohvaliti. Najprije u Split, pa potom u Zadar premještena je i mlada glumica Mia Oremović, koja je najtočnije opisala ovo burno razdoblje tranzicije u kazalištu:

Mi smo morali otići iz Zagreba. To je tada bilo gotovo prirodno, normalno. Naime, glumci koji su bili na terenu, kako se danas kaže, došli su u Zagreb i trebalo je za njih mjesta pa su mnogi glumci iz Zagreba premješteni u druge gradove i gradiće. ${ }^{22}$

18 Dopis glumice Jelene Manjkovske Upravi HNK, 22. VI. 1945., HAZU, Odsjek za povijest hrvatskog kazališta, Muzejsko-kazališna zbirka dokumenata: 15583.

19 Dopisi glumice Bogumile (Mile) Nučić-Careve Upravi HNK, 2. IX. 1945. i 21. III. 1947., HAZU, Odsjek za povijest hrvatskog kazališta, Muzejsko-kazališna zbirka dokumenata: 15351 i 15341.

20 Dopis glumca Borisa Vrsalovića, 6. VII7. 1945., HAZU, Odsjek za povijest hrvatskog kazališta, Muzejsko-kazališna zbirka dokumenata: 15352.

21 Molba glumca Radojka Ježića, 4. VII. 1945., HAZU, Odsjek za povijest hrvatskog kazališta, Muzejsko-kazališna zbirka dokumenata: bez vidljiva broja.

22 Antonija Bogner-ŠSABAN, Zaustavljeni trenuci glume, Zagreb 2000., 25. 
Istovremeno $s$ jadima kazališnih umjetnika koji su morali otići iz Zagreba, u pripremi su bili izbori za nove gradske zastupnike. Na Jelačićevu trgu održava se (13. X. 1945.) masovan predizborni miting - sve je prepuno zastava koje vijore, nose se transparenti, sa zvučnika se pušta glazba i izvješća o dotadašnjem radu privremenoga Gradskog odbora. Sljedećeg dana, u nedjelju, održavaju se izbori, a u ponedjeljak 15. listopada svečano se, na istom trgu, proglašavaju rezultati: među izabranim gradskim zastupnicima jest i Dubravko Dujšin, glumački prvak i redatelj HNK-a, po mnogima „najviđeniji javni radnik“23 u zemlji, kojeg je vijest zatekla u šetnji - mnogi su mu prolaznici pristupali i čestitali. Bio je to prvi put u povijesti grada Zagreba, ali i u povijesti hrvatskog kazališta uopće da glumac dobiva javnu funkciju izvan svog zvanja. Nova dužnost "gradskog oca“ dirnula ga je te je odmah obećao „doprinijeti svoj udio na sređivanju prilika u Zagrebu, a to znači i u Hrvatskoj“, i „uložiti sve što bude do mene da se ublaže oštrine, izglade neravnine, da bi napokon došli u eru mirne izgradnje. ${ }^{\text {"24 }}$

Ovo turbulentno razdoblje poslijeratne kadrovske politike u kulturi i prosvjeti vlast je obično opisivala kao brigu „o pravilnom rasporedu naših kadrova uzimajući u obzir njihove stručne sposobnosti, kao i mogućnost njihova daljnjeg razvoja “25, no neki su bili drugačijeg mišljenja te su spomenuto na primjeru HNK-a bili skloni označiti kao čistke i „ulazak Staljinova duha u našu žutu kuću ${ }^{\text {"26, }}$, što je, po svemu sudeći, potrajalo sve do dolaska Ranka Marinkovića na čelo Drame ljeti 1946., kada taj mladi, ali već istaknuti kazališni kritičar i budući bard hrvatske književnosti započinje stvaranje jedinstvenoga ansambla Drame.

Što se, pak, angažiranja novih članova tiče, ali i produženja angažmana starima, prednost su i dalje imali oni kandidati koji se nisu „ogriješili o današnju vlast“, niti su „stali na pripomoć okupatoru“ ili bili članovi „kakove protunarodne organizacije“, već su prednost imali oni koji su „pripomagali NOB-u“ ili bili u partizanima i dobrog su „moralnog i političkog vladanja", tj. ispravni. ${ }^{27}$ Ipak, partizanski staž nije uvijek pomagao, naročito ako nije bilo dovoljno umjetničke vještine: nakon ranjavanja u partizanima, izvjesni Josip Horvat, glazbenik, demobiliziran radi nastavka školovanja, poslao je molbu za angažman u orkestru HNK-a, tvrdeći da uz to ima pravo i na ostale „materijalne prinadležnosti“ kao

23 Branislava Vojnović (prir.), Zapisnici Politbiroa Centralnog komiteta Komunističke partije Hrvatske 1945. - 1952., sv. I.: 1945. - 1948., Zagreb 2005., 66.

24 Igor Mrduljaš, Dubravko Dujšin - poslovi i dani, Zagreb 1988., 358. Nažalost, skora smrt (30. I. 1947.) spriječit će Dujšina u ovom naumu. Nakon 25 godina duge i izuzetno plodne karijere, umro je u 53. godini od srčanog udara. Dujšin je, prema mnogima, bio ponajbolji hrvatski glumac svih vremena kojeg je krasio „dostojanstven korak, svečana gesta uz brončani metal njegova punog glasa“, usto i „velika vještina prerušavanja, bogata tonska modulacija $\mathrm{i}$ smisao za igru“, koji su mu omogućavali da igra širok dramski i komedijski repertoar. Bio je usto i plodan redatelj, kojem su priznavali velike pedagoške sposobnosti, temeljito poznavanje scene i njegovan ukus. Bolest koju je vukao od čestih boravaka u zatvoru tijekom NDH dotukla ga je na vrhuncu karijere. Zauvijek se oprostio od scene u Krležinoj Gospodi Glembajevima samo dva dana prije smrti (28. I. 1947.), u kojoj je igrao Ignjata Glembaja, a koji u II. činu, nakon velike svađe sa sinom Leoneom, također umire od srčanog udara. Kazališni list (Zagreb), br. 24 , 9. 2. 1947., 1-9.

25 Pravorijek Disciplinskog suda Ministarstva prosvjete, 2. X. 1947. HAZU, Muzejsko-kazališna zbirka dokumenata, Kartoteka osoba, fasc. Ivo Jakšić-Leitner.

26 E. Gerner, Oteto zaboravu, 10-11.

27 Više osobnih spisa angažiranih umjetnika (violinist Stevan Mezei, plesači Zlatica Stepan i Radoslav Nikolić, scenski radnik Vinko Pasarić, krojačice i garderobijerke Ivana Mazić, Ivka Maurer i Vlasta Uršić), HR-HDA-291, MINPRO RH, fasc. 13.3.4. VIII 46a - Osobni spisi: 46070, 47260, 47409, 61769, 66664, 67594, 70100., kut. 56. 
što su: hrana u mjestu stanovanja na određen broj dana, civilna odjeća i novčana pomoć. Posao nije dobio. ${ }^{28}$

Uz svaku je prijavu za posao trebalo ishoditi i Potvrdu o valjanom ponašanju, a za to je bio nadležan Upravni odbor Gradskog narodnog odbora za Grad Zagreb. Balerina Đurđa Đurđan, članica ansambla od kraja 20-ih godina, dobila je radi razvrstavanja u višu plaćevnu grupu uvjerenje od toga tijela da je „od rođenja pa do danas bila dobrog moralnog vladanja." ${ }^{29}$ Suprotno od onih valjana i ispravna ponašanja, oni koji su otvoreno podržavali ustaški režim nisu mogli očekivati posao u HNK-u i njihove su karakteristike (u kojima se moralo odgovoriti na pitanja o „ličnom i porodičnom životu - dobre i loše strane“, discipliniranosti, marljivosti, izvršavanju postavljenih zadataka i općoj sposobnosti u radu, odnosu prema rukovodiocima, političkom držanju prije, za vrijeme rata i poslije oslobođenja) bile otvoreno neprijateljske. ${ }^{30}$ Tako su intendant Tijardović i glavni tajnik Ivan Dončević (usto i sekretar partije u HNK-u te član Agitpropova Odjela za književnost, u koji je uglavnom spadalo i kazalište) uputili Ministarstvu prosvjete u listopadu 1946. dopis u kojem odbijaju molbu krojača Slavka Jambrešića jer je „za vrijeme okupacije bio povjerljiva ustaška osoba“, a imao je „,veze i sa Nijemcima“ te bio „Homoseksualac. Potpuno negativan karakter.“ Stoga su bili mišljenja da je za njega zaposlenje „nemoguće, ne samo u ovom zavodu, već ni u ostalim kazalištima NRH.“31

\section{4 .}

U vrijeme kada intendant Tijardović kreće u pripreme za svoju prvu sezonu, koja će programski predstavljati početak od Partije nametnute doktrine socijalističkoga realizma u umjetnosti, razdoblja koje će pod budnim okom Odjela za agitaciju i propagandu (Agitprop) potrajati sve do kraja 1949., a tijekom kojeg će se i kazališni umjetnici teško boriti za svaki slobodan dah ${ }^{32}$, grad Zagreb se gotovo isključivo snabdijeva racionaliziranim artiklima preko državnih ustanova jer je trgovački distribucijski aparat još preslab pa su repovi u trgovinama redovita pojava. ${ }^{33}$ Ipak, odmah od jeseni 1945. Gradski narodni odbor uvažava molbu uprave HNK-a, čime pokazuje „osobito razumijevanje za ovu kulturnu i umjetničku ustanovu grada Zagreba“, uz to i „mnogo dobre volje i sklonosti da u svoj novi proračun unese izvjesnu svotu kao subvenciju kazališta u Zagrebu. “34 U razdoblju 1945. - 1948. go-

28 Isto: 70098 , kut. 56.

29 Uvjerenje o vladanju, 22. VII. 1946., HAZU, Muzejsko-kazališna zbirka dokumenata, Kartoteka osoba, fasc. Đurđa Đurđan.

30 Karakteristika glumca D. Knapića, HAZU, Muzejsko-kazališna zbirka dokumenata, Kartoteka osoba, fasc. Dragan Knapić, dokument bez datuma.

31 HR-HDA-291, MINPRO RH, fasc. 13.3.4. VIII 46a - Osobni spisi: 72662., kut. 56.

32 O kulturnoj politici i programskim smjernicama socrealizma u kulturi i u kazalištu, u: Ljubodrag Dimić, Agitprop kultura. Agitpropovska faza kulturne politike u Srbiji 1945. - 1952., Beograd 1988.; Branka Doknić, Milić F. PETrović i Ivan Hofman (prir.), Kulturna politika Jugoslavije 1945. - 1952. Zbornik dokumenata, knj. I.-II., Beograd 2009.

33 B. Vojnović (prir.), Zapisnici Politbiroa, sv. I., 208-209; Ista (prir.), Zapisnici Politbiroa Centralnog komiteta Komunističke partije Hrvatske 1945. - 1952., sv. II.: 1949. - 1952., Zagreb 2006., 229.

34 Kazališni list (Zagreb), br. 5, 13. 10. 1945., 12. 
dine, iz proračuna Narodne Republike Hrvatske za kulturu i prosvjetu izdvajalo se između 15 i $24 \%$, a kasnije se ta stavka ustalila na oko $20 \%$. Ukupan je proračun npr. 1947. iznosio 6,295.417.000 dinara, a za 54 institucije prosvjete i kulture izdvojeno je 139 milijuna. Najviše se sredstava od toga odvajalo upravo za HNK - 25,2 milijuna. ${ }^{35}$

Za to vrijeme opskrba stanovništva nastavlja se sve do kraja 1952. obavljati planskom raspodjelom živežnih namirnica i industrijskih proizvoda, skupoća je velika, o čemu se često govori i na sjednicama Politbiroa CK KPH, čiji članovi smatraju da ona šteti raspoloženju grada Zagreba pa „ljudi na svakom koraku oštro reagiraju (...), ljudima nije jasno zašto su se kroz tako kratko vrijeme (radi se o 1949. - op. a.) digle tako visoke cijene." Iako je opskrba mesom bila nešto bolja od one voćem i povrćem, slaba je i dalje ona brašnom te se na najvišem partijskom tijelu u Hrvatskoj priznaje da „dugujemo građanima kukuruza i pšeničnog brašna." Usto, seljaci koji donose svoju robu u Zagreb iz okolnih mjesta putuju uglavnom vlakom, za koji su cijene previsoke te se i taj trošak odražava na cijene njihovih proizvoda, ,što ide na račun radnika." ${ }^{36}$ Ipak, komunalni se život uskoro stabilizira, i to u skladu s Petogodišnjim planom iz 1947., ali i zahvaljujući brojnim radnim akcijama na kojima sudjeluju i umjetnici HNK-a te donacijama UNRA-e. ${ }^{37}$ Kultura grada Zagreba slijedit će poratnu sudbinu svoga grada: nakon nagle obnove kazališta i izdavaštva ujesen 1945., ostatak kulturnog života u Zagrebu tek se izdiže ispod minimuma: programi radiostanice oskudni su, tisak nedovoljno raznovrstan, koncertni se život tek ponovno uspostavlja, a u kinima se prikazuju filmovi sovjetskih idejnih i estetskih opredjeljenja pa HNK, do kraja 1948. jedino kazalište u Zagrebu, u razdoblju koje opisuje ovaj članak zadržava središnje mjesto javnoga života grada.

Takav njegov položaj u društvu i gradu ponajbolje ilustriraju brojna svečana događanja u režiji Partije kada tijekom prvih poratnih sezona u Zagrebu redovito borave različite delegacije i pojedinci iz Sovjetskog Saveza. Naime, na početku procesa obnove kulturnog i prosvjetnog života, brojne republičke i gradske prosvjetno-kulturne institucije redovito obilaze sovjetske delegacije profesora, književnika, glumaca, novinara itd., a razlog tomu bio je, između ostaloga, i (pre)malen broj komunista među nastavnim i umjetničkim kadrom, „ali i cjelokupnom inteligencijom. “'38 Tako je već u rujnu 1945. za delegaciju Sveslavenskog komiteta iz Moskve (koju je u Zagrebu ugostio CK KPH, uz izvršnu pomoć Agitpropa) organiziran u kazalištu „birani dramski i glazbeni raspored“s nizom recitacija i popijevki o

35 Za usporedbu, osječki HNK dobio je 6,7 milijuna, splitski HNK 7,1 milijun, a kazališta u Zadru, Varaždinu, Šibeniku i Dubrovniku po 1,6 milijuna. Za daljnju usporedbu - državnoj upravi i administraciji u resoru prosvjete i kulture dodijeljeno je 17,9 milijuna, Filozofskom fakultetu 4 milijuna, Sveučilišnoj knjižnici 2,3 milijuna, a JAZU 400.000 dinara. (Katarina SpeHnJaK, Javnost i propaganda. Narodna fronta u politici i kulturi Hrvatske 1945. - 1952., Zagreb 2002., 177)

36 B. Vojnović (prir.), Zapisnici Politbiroa, sv. I., 208-209; Ista (prir.), Zapisnici Politbiroa, sv. II., 229.

37 SAD je s Velikom Britanijom i Kanadom osnovao i financirao Administraciju Ujedinjenih naroda za pomoć i obno$\mathrm{vu}$ (UNRRA - United Nations Relief and Rehabilitation Administration), s ciljem pomaganja obnove ratom uništenih zemalja. U razdoblju 1945. - 1946. Jugoslavija je dobila preko dva i pol milijuna dolara, a od pomoći je najznačajnija bila ona zdravstvena, potom građevinska, prehrambena i tekstilna. O tome više u: Branko Petranović, Istorija Jugoslavije 1918 - 1988, knj. 3.: Socijalistička Jugoslavija, Beograd 1988., pogl. „Državna privreda i njene protivurečnosti“, 79-82.

38 B. Doknić, M. F. Petrović i I. Hofman (prir.), Kulturna politika Jugoslavije, knj. I., 31. 
temi slavenstva, partizanske borbe i Tita, a uz, u to doba obveznu, Mitraljezu Natka Devčića (ujedno člana Agitpropa), Zajc-Baranovićev Svatovac i prvi čin Smetanine Prodane nevjeste. Nakon toga je oduševljeni tisak prenio izjavu gostiju da je „zagrebačko kazalište na vrlo visokom stupnju (...) a Zagreb ostavlja na inozemca utisak vrlo kulturnog i srdačnog grada.“

Slična gostovanja mnogih scensko-glazbenih trupa, orkestara i pojedinaca iz Sovjetskog Saveza izmjenjivala su se s gostovanjima domaćih kazališta i solista iz cijele zemlje, u prvom redu beogradskih te ljubljanskih, no u lipnju 1947. prilikom zatvaranja sezone 1946./1947. ugošćena je prvi put u našoj kazališnoj povijesti hrvatska Drama novoosnovanog (1946.) Narodnog kazališta Rijeka. Njihove su predstave nagnale kritičara Marijana Matkovića na ekstatičan zapis: „Nestao je nakazni most na Rječini načičkan fašističkim perjanicama i kraljevsko-jugoslavenskim žandarskim kapama; preko umjetne bivše granice prostrujala je slobodna domaća riječ, decenijama progonjena (...) odjekuje u kazalištu, po vanjskoj arhitekturi tako sličnom zagrebačkom teatru. ${ }^{\text {"39 }}$

U skladu s novim ritualima i običajima, s pomoću kojih nove političke elite nastoje iskazati svoj legitimitet u novim društvenim okolnostima, uz česta narodna slavlja na središnjem zagrebačkom trgu i na drugim mjestima u Zagrebu, ali i u tvorničkim halama, školama i poduzećima, različiti se programi brojnih nositelja vlasti (obično pod visokim protokolom, a obvezno oni vezani uz Dan Republike, prvomajske svečanosti, Josipa Broza Tita i brojne datume važne za zemlju i poredak) odvijaju i u kazalištu. ${ }^{40}$ Tako se iz sezone u sezonu na objema scenama smjenjuju priredbe u organizaciji vojske i civila, profesionalnih kazališnih trudbenika i amatera, antifašističkih organizacija rođenih za vrijeme borbe i novonastalih poslije oslobođenja „da budu izraz onoga što narod osjeća i misli. “41 Brojni su tih godina svečani programi kojima različite društveno-političke organizacije obilježavaju događanja iz ratnih dana, slave se obljetnice posvećene važnim datumima iz NOB-a, rođendani povijesnih ličnosti (književnika, glumaca, političara...) iz dalje i bliže domaće, ali i sovjetske prošlosti, a organiziraju se i različita natjecanja amaterskih ansambala. Tako je krajem 1947. u organizaciji Glavnih i jedinstvenih sindikata Hrvatske, u Malom kazalištu u Frankopanskoj ulici, tijekom šest večeri i u 52 točke nastupilo čak 13 plesnih grupa, dva tamburaška zbora, sedam glumačkih družina, simfonijski orkestar, četiri limene glazbe, tri mandolinska i dva mješovita orkestra te 18 pjevačkih zborova s više od 2.000 glazbenika, pjevača, plesača, glumaca, i recitatora. ${ }^{42}$

U središnju ložu gledališta zalaze i čelnici drugih socijalističkih zemalja - na izmaku prve Tijardovićeve sezone, krajem lipnja 1946., u posjet Zagrebu stiže Enver Hodža, predsjednik Vlade Narodne Republike Albanije (u svim programima navodi se kao gospodin ili generalpukovnik), za kojeg je tom prilikom prikazana Puccinijeva Madame Butterfly. ${ }^{43}$ Slič-

\footnotetext{
39 M. Matković, Dramaturški eseji, Zagreb 1949., 390.

40 O političkim ritualima socijalističke vlasti, u: Reana Senjković, „Politički rituali“, u: Jasmina BavolJak (ur.), Politički rituali / Katalog izložbe Refleksije vremena 1945.-1955.: Galerija Klovićevi dvori, Zagreb, 12. 12. 2012. - 10. 3. 2013., Zagreb 2012., 202-227.

41 Mato Grković, „Malo kazalište 1945. - 1953.“, u: Hrvatsko narodno kazalište. 20 godina rada HNK u socijalističkoj Jugoslaviji (ur. Pavao Cindrić), Zagreb 1965., 19.

42 Isto, 21.

43 HAZU, Programske cedulje sezona HNK, 1945./1946., 28. VI. 1946.
} 
nim događanjima kojima se ujedno slavi i „bujni politički i kulturni život jugoslavenskih naroda i Grada Zagreba “44 obvezno prisustvuju gradski i republički partijski prvaci te tako obje kazališne zgrade postupno postaju značajno žarište gradskog i republičkog javnog života. To je doba kulturnog, radnog i stvaralačkog zanosa, koje odgovarajući odraz nalazi i u djelatnostima HNK-a - ono svojim raznovrsnim repertoarom privlači nepregledne redove posjetilaca pred svojom blagajnom. Primjerice, čitava sezona 1946./1947., u kojoj je u kazalištu bilo čak 436.536 posjetitelja, odvijala se $s$ idejom neprekidne borbe za što kvalitetnije izvedbe i za što viši umjetnički domet, a najviše je pozornosti posvećeno odgajanju nove kazališne publike. ${ }^{45}$

Bïlo tadašnjega Zagreba, sjedinjenog sa svojim jedinim kazalištem ${ }^{46}$, možda najbolje ilustriraju događanja na Dan žalosti (1. veljače 1947.) za spomenutim glumačkim prvakom Dubravkom Dujšinom, kada kazalište ostaje zatvoreno, a sprovod prvoga među glumačkim prvacima organizira se uz iznimno visok protokol, ostavši do danas jednim od najvećih u hrvatskoj povijesti. ${ }^{47}$ Nepregledna povorka, u kojoj su bili istaknuti građani, umjetnici, kulturni radnici i političari, prostirala se toga dana od kazališta sve do Mirogoja. Dva dana kasnije sjednica Gradske skupštine, u kojoj je Dujšin bio odbornik, započela je pozivom potpredsjednika Gradskog izvršnog odbora Mirka Pavlekovića odbornicima da ustajanjem i šutnjom odaju počast uspomeni na velikana. ${ }^{48}$

Razdoblje je to koje Marijan Matković - misleći kao kazališni kritičar prvenstveno na kazališne, ali i šire, kulturne prilike u Hrvatskoj - naziva revolucionarnim prelaznim periodom, koji će svoj kraj, što se HNK-a tiče, dočekati 1949. godine, odlaskom Tijardovića s mjesta intendanta te dolaskom upravo Matkovića na to mjesto, a usto koincidirati i s pripremama za postupno uvođenje nove doktrine samoupravljanja u sva državna poduzeća i ustanove, slijedom toga i u kazališta. ${ }^{49}$ Načelnika Gradskoga odbora Sailija je na mjestu pr-

$\overline{44}$ M. Grković, „Malo kazalište 1945. - 1953.“, 19.

45 Muzejsko-kazališna zbirka dokumenata: 3056.

46 U rujnu 1948., a u skladu s Petogodišnjim planom i tumačenjima zaključaka V. Kongresa KPJ (Beograd, 1948.), u Zagrebu se osniva (prvo) Zagrebačko dramsko kazalište, koje je imalo sjedište na Kaptolu, gdje će uskoro s radom započeti njegov sljednik - kazalište „Komedija“ (1950.) te HNK. U isti se plan uskoro uklopio i osnutak Pionirskoga kazališta (1948., danas ZKM), koje je, u nedostatku prostora, svoje brojne produkcije još pet godina izvodilo na sceni Maloga kazališta HNK-a i Zemaljskog kazališta lutaka (danas Zagrebačko kazalište lutaka), nastaloga od jezgre Habunekove „Družine mladih“ iste godine. Tada HNK napokon prestaje biti jedino kazalište u Zagrebu.

47 Od Dujšina se u foajeu HNK-a najprije oprostio intendant Tijardović, zatim je govorio Zoran Palčok, pomoćnik novoga ministra prosvjete dr. Ive Babića (1946. - 1951.) te potpredsjednik Gradskog NO-a Andrija Mohorovičić, potom dr. Ante Kuntarić uime frontovskih organizacija. Na Mirogoju su nad otvorenim grobom govorili Hinko Nučić (uime članova Drame) i Mato Grković (uime sindikalne podružnice). Potom su uslijedili govori uime Saveza prosvjetnih radnika Jugoslavije i Zemaljskog odbora prosvjetnih radnika Hrvatske (Josip Radovčić). Uime Narodnog pozorišta u Beogradu govorio je direktor Drame Velibor Gligorić, a uime kolega iz beograskog pozorišta bivši dugogodišnji član zagrebačke Drame Strahinja Petrović, uime ljubljanske Drame Bojan Stupica te uime mariborske Jaroslav Dolar. Uime varaždinskoga kazališta govor je održao Mirko Perković, uime zadarskoga Emil Karasek, a uime riječkog intendant Đuro Rošić. Pogrebu su prisustvovali i predstavnici sarajevskog, osječkog i banjalučkog kazališta. Uprava je dobila niz brzojava sućuti od organizacija i pojedinaca iz cijele Jugoslavije. Kazališni list (Zagreb), br. 24, 9. 2. 1947., 8-9; HAZU, Programske cedulje sezona HNK, 1947./1948., 1. 2. 1947.

48 Skraćeni zapisnik IX. redovnog zasjedanja GNO u Zagrebu održanog na dan 3. veljače u 1947. u Gradskoj vijećnici, Službeni glasnik Gradskog narodnog odbora u Zagrebu (Zagreb), god. 1., br. 6, 8. 2. 1947., 71.

49 Više o intendanturi M. Matkovića u HNK, u: S. BANović, „Marijan Matković - intendant HNK u Zagrebu (1949. - 1953.). Između politike i potrage za novim kazališnim stilom i novom domaćom dramom“, Kronika Zavoda za povijest hrvatske književnosti, kazališta i glazbe, XVII/2015., br. 32, 13-31; IstA, Službeni izlaz, Zagreb $2018 ., 95-116$. 
vog čovjeka grada naslijedio Mika Špiljak, koji će tu dužnost obavljati samo do 1950., ali će istodobno biti i na funkciji sekretara Gradskog komiteta KP-a Zagreb, ali i člana Politbiroa CK KPH. ${ }^{50} \mathrm{Na}$ kraju svog kratkog mandata, ljeti 1950., na sjednici tog najvišeg partijskog tijela u Republici Hrvatskoj, Špiljak rezignirano izjavljuje da u Zagrebu vlada „politička depresija“ te da se društveni procesi odvijaju „tiho i bez oduševljenja. “51

\section{6.}

Istodobno, u HNK-u se, usprkos letargiji koju spominje Špiljak, priprema značajan umjetnički pomak: u Zagreb se nakon šestogodišnjega izbivanja definitivno vraća Branko Gavella koji će, u sezonama koje slijede, uz osnivanje Akademije za kazalište iste godine, pokrenuti i zavidnu konsolidaciju ansambla Drame. Intendant Matković je dovođenjem Gavelle u Zagreb uspio zadržati kazalište u središtu kulturnih zbivanja, iako to više nije bilo lako jer, uz nova kazališta, grad sada ima i novu koncertnu dvoranu u Domu JNA te koncertnu dvoranu „Istra“, izgrađena je ljetna pozornica s 1.400 mjesta za scensko-glazbene i filmske priredbe na Sofijinu putu te više novih domova kulture. Iste se godine Miroslav Krleža upušta u pothvat pokretanja Leksikografskog zavoda (osnovanog 5. X. 1950.), kao znanstvene ustanove saveznog značenja. Zagreb potom nastavlja svoju misiju kulturnoga središta nizom novih inicijativa suvremenih stremljenja, posebice u likovnoj umjetnosti i glazbi. Prema mišljenju istaknutoga glazbenog umjetnika Emila Cossetta, nastupa „plimni val kulturne euforije" 52 koji glavni grad Republike Hrvatske prožima intenzivnim kulturnim rastom i potrebama sve brojnije publike, koju nije više mogao u potpunosti zadovoljiti teatar čije će dramske izvedbe uskoro započeti pratiti i novo ime hrvatske kazališne kritike, Vladan Desnica. ${ }^{53}$ Unatoč naporima agilnoga intendanta Matkovića, koji će iz političkih razloga biti prisiljen otići iz kazališta ujesen 1953., ono definitivno gubi korak s drugim, novopokrenutim suvremenim inicijativama u gradu Zagrebu te prodorom popularne kulture i masovnih medija u svakodnevni život. Usto, kazalište će potresti brojne unutrašnje krize, od kojih će se ona najveća otvoriti nakon odcjepljenja dijela ansambla na čelu s Gavellom u proljeće 1953., čime će započeti život Zagrebačkog dramskog kazališta. ${ }^{54} \mathrm{HNK}$ će tako ostati bez svoje druge pozornice, koja je desetljećima služila kao ventil za uspješno manipuliranje trima ansamblima, što će, usprkos kasnijim razdobljima procvata Opere i

50 „Špiljak, Mika“, Hrvatska enciklopedija (http://www.enciklopedija.hr/natuknica.aspx?id=59840). Usp. Miroslav ŠAšrć, „Zagrebački gradonačelnici“, Radio Zagreb, 18. 5. 2013. (http://radio.hrt.hr/radio-sljeme/clanak/feljton-zagrebacki-gradonacelnici-iv-dio/16488/)

51 B. Vojnović (prir.), Zapisnici Politbiroa, sv. II., 14. 8. 1950., 435.

52 Emil Cossetto, „Godine entuzijazma“, u: Zagreb i Hrvatska u Titovo doba (ur. Tomislav Badovinac), Zagreb 2004., 299.

53 Desničin kratki staž kazališnog kritičara u časopisima Kolo i Scena valjalo bi obraditi u posebnom članku. Više o tome u: N. BATušić, Hrvatska kazališna kritika, Zagreb 1971., 274-277.

54 Više o tome u: S. BANović, „Branko Gavella i oblikovanje naših kazališnih politika u XX. stoljeću - između politike i ideje Novoga teatra", u: Krležini dani u Osijeku 2013. - supostojanja i suprotstavljanja u hrvatskoj drami i kazalištu (prir. Branko Hećimović), Zagreb - Osijek 2014., 53-74. 
Baleta te njihovu uspješnom pozicioniranju na gustoj mapi inozemnih gostovanja, ostati do danas nerješiv problem svake vladajuće kulturne politike.

\title{
$\cos$
}

\author{
THE THEATRE AND THE CITY: \\ CONTRIBUTIONS TO THE HISTORY OF ZAGREB \\ IN LIGHT OF THE DEVELOPMENT OF ITS THEATER IN THE \\ WAKE OF WORLD WAR II (I945 - I950)
}

Summary: The article discusses the correlation between post-war history of Zagreb and the development of its theater, whose name was changed to the Croatian National Theater immediately after the Partisan troops entered the city in May 1945. Following the formation of the new government, the basic principles of the emerging educational and cultural policies of the institution, which had been defined by the Communist party even before the war as central to the revolutionary struggle, would be implemented in their entirety. Subsequently, cultural life in Croatia and Yugoslavia in general was given an impetus in terms of ample opportunities for growth, and the theater was no exception. In the summer of the same year, the new management of the Croatian National Theater, with Ivo Tijardović at the helm, began preparations for its first season, while virtually all cultural and educational institutions were entangled in excruciating honor court trials and punishments, the cultural life of Zagreb was infused with vibrancy in spite of the difficulties inherent to postwar economy. Although the citizens still subsisted on rationed foods supplied by the state, since normal distribution channels had not yet been re-established, i. e. despite economic, financial and infrastructural dire states, as early as September 1945, the theater begins putting on a demanding repertoire, with plays performed on two stages. However, this enthusiasm and nearunprecedented flourishing of both the dramatic and musical arts is accompanied by the tightening of state control and surveillance, as a consequence of the "agitpropization" of society. This in turn affects and transforms the repertoire, as well as the expectations of the audience as well as the critics - in short, entire cultural microcosm of Zagreb. It can be said that this is the time of great euphoria, which puts Zagreb in the path of a tidal wave of cultural growth, thus enabling the city to confirm its status as the epicenter of numerous contemporary movements in arts and sciences during the 1950s. The Croatian National Theater, as the largest and the most representative of all cultural institutions of the People's Republic of Croatia, will also provide a space for the representation for the new social and political paradigm, and many events will be put on with the express goal of promoting the theater and the city of Zagreb as the cultural and political center of Croatia and Yugoslavia

Key words: The People's Republic of Croatia, Zagreb, new cultural and theater policies, the Croatian National Theater, Zagreb, Agitprop culture 


\section{Izvori}

Hrvatski državni arhiv (HR-HDA)

HR-HDA-291, fond Ministarstvo prosvjete Republike Hrvatske (MINPRO RH), fasc. 13.3.4. VIII 46a - Osobni spisi: 10514, 46070, 47260, 47409, 61769, 66664, 67594, 70098, 70100, 72662 , kut. 56.

HR-HDA-306, fond Zemaljska komisija za utvrđivanje zločina okupatora i njihovih pomagača Hrvatske, Anketna komisija za utvrđivanje zločina kulturne suradnje s neprijateljem (AK) 1941. - 1946., kut. 686.

HR-HDA-1220, fond Komisija za agitaciju i propagandu CK KPH 1945. - 1954. (Agitprop), fasc. Kazališta - HNK u Zagrebu, 1946. - 1950., kut. 10.

HR-HDA-1220, fond Komisija za agitaciju i propagandu CK KPH 1945. - 1954. (Agitprop), fasc. Kult. umj. rad (I. dio) 1945./1954., kut. 10.

Zavod za povijest hrvatske književnosti, kazališta i glazbe Hrvatske akademije znanosti i umjetnosti (HAZU), Odsjek za povijest hrvatskog kazališta

Muzejsko-kazališna zbirka dokumenata: 15331, 15341, 15351, 15352, 15583, 18068, 18117.

Muzejsko-kazališna zbirka dokumenata, Kartoteka osoba: Ivo Jakšić-Leitner, Đurđa Đurđan, Dragan Knapić.

Programske cedulje sezona HNK, 1945./1946. i 1947./1948.

Zbirka dokumenata Hrvatskoga narodnog kazališta (Zbirka HNK)

Kazališni list (Zagreb), br. 5, 13. 10. 1945., 12; br. 24, 9. 2. 1947., 1-9.

Službeni glasnik Gradskog narodnog odbora u Zagrebu (Zagreb), god. 1., br. 6, 8. 2.1947.

Pero Budak, Živeći život (rukopis u arhivi Nevena Budaka)

Branka Doknić, Milić F. Petrović i Ivan Hofman (prir.), Kulturna politika Jugoslavije 1945. 1952. Zbornik dokumenata, knj. I.-II., Beograd 2009.

Irena Kolesar, „Dnevnički zapisi i sjećanja iz partizana. Izvodi 1943.-1945. godina“ (odabrala i priredila Mira Šuvar), Hrvatska ljevica, VIII/2002., br. 9, 30-32.

Branko Polić, Imao sam sreće. Autobiografski zapisi, II. dio (1. XI. 1942. - 22. XII. 1945.), Zagreb 2006.

Branislava Vojnović (prir.), Zapisnici Politbiroa Centralnog komiteta Komunističke partije Hrvatske 1945. - 1952., sv. I.: 1945. - 1948., Zagreb 2005.

Branislava Vojnović (prir.), Zapisnici Politbiroa Centralnog komiteta Komunističke partije Hrvatske 1945. - 1952., sv. II.: 1949. - 1952., Zagreb 2006.

\section{Literatura}

Snježana BANović, „Branko Gavella i oblikovanje naših kazališnih politika u XX. stoljeću - između politike i ideje Novoga teatra“, u: Krležini dani u Osijeku 2013. - supostojanja i suprotstavljanja u hrvatskoj drami i kazalištu (prir. Branko Hećimović), Zagreb - Osijek 2014., 152-170.

Snježana BANović, Država i njezino kazalište, Zagreb 2012.

Snježana BAnović, „Marijan Matković - intendant HNK u Zagrebu (1949. - 1953.). Između politike i potrage za novim kazališnim stilom i novom domaćom dramom", Kronika Zavoda za povijest hrvatske književnosti, kazališta i glazbe, XVII/2015., br. 32, 13-31. 
Snježana BANović, Službeni izlaz, Zagreb 2018.

Nikola BATušić, Hrvatska kazališna kritika, Zagreb 1971.

Nikola BATušić, Povijest hrvatskoga kazališta, Zagreb 1978.

Antonija Bogner-ŠABAN, Zaustavljeni trenuci glume, Zagreb 2000.

Emil Cossetro, „Godine entuzijazma“, u: Zagreb i Hrvatska u Titovo doba (ur. Tomislav Badovinac), Zagreb 2004.

Ljubodrag Dimić, Agitprop kultura. Agitpropovska faza kulturne politike u Srbiji 1945. - 1952., Beograd 1988.

Eliza Gerner, Oteto zaboravu, Zagreb 1995.

Mato Grković, „Malo kazalište 1945. - 1953.“, u: Hrvatsko narodno kazalište. 20 godina rada HNK u socijalističkoj Jugoslaviji (ur. Pavao Cindrić), Zagreb 1965.

Ivica Krizmanić i Ljudmil Gotcheff, Naša kazališta. Dokumenti naše stvarnosti, Zagreb 1955.

Marijan MatKović, Dramaturški eseji, Zagreb 1949.

Igor Mrduljaš, Dubravko Dujšin - poslovi i dani, Zagreb 1988.

Branko Petranović, Istorija Jugoslavije 1918 - 1988, knj. 3.: Socijalistička Jugoslavija, Beograd 1988.

Drago Roksandić i Vlatka Filipčić Maligec, Prvi kongres kulturnih radnika Hrvatske (Topusko, 25. - 27. lipnja 1944.). Između „mjesta pamćenja i kritičke refleksije“, Zagreb 2016.

Reana Senjković, „Politički rituali“, u: Jasmina Bavoljak (ur.), Politički rituali / Katalog izložbe Refleksije vremena 1945.-1955.: Galerija Klovićevi dvori, Zagreb, 12. 12. 2012. - 10. 3. 2013., Zagreb 2012., 202-227.

Katarina SpehnjaK, Javnost i propaganda. Narodna fronta u politici i kulturi Hrvatske 1945. - 1952., Zagreb 2002.

Mladen Žigrović, $U$ žitu i kukolju, München - Barcelona 1986.

\section{Mrežne stranice}

„Prof. dr. Antun Kajfeš“, Hrvatski državni arhiv (http://daz.hr/prof-dr-antun-kajfes/)

Miroslav ŠAšić, „Zagrebački gradonačelnici“, Radio Zagreb, 18. 5. 2013. (http://radio.hrt.hr/radiosljeme/clanak/feljton-zagrebacki-gradonacelnici-iv-dio/16488/)

„Špiljak, Mika“, Hrvatska enciklopedija

(http://www.enciklopedija.hr/natuknica.aspx?id=59840) 
